\title{
The Control Of Rural Environmental Problems Through Institutional Approach In Wajo Regency
}

\author{
Muhlis Madani ${ }^{1}$, Zulfan Nahruddin ${ }^{1}$ \\ \{muhlis.madani@unismuh.ac.id $\left.{ }^{1}\right\}$ \\ Universitas Muhammadiyah Makassar
}

\begin{abstract}
This research identifies the circumstances and rural environmental problems and analyzes the control efforts of rural environmental problems through the institutional approach in Wajo. The research method joint with quantitative and qualitative. The Informants comprised three villages Marannu, Simpellu, and Tangkoro in Wajo. Activities in the data analysis were data reduction, display data, and data verification. The results showed that the solution is still less optimal such as household waste, social problems, and the seedy neighborhood despite involved the PKK (Development of Family Welfare), The Institute for Youth, Department of Hygiene, and Majelis Taqlim. It still needs to maximize on the institutional aspects while the pest problem on agricultural land should rank because of the support of farmers' group still less contribution. In another hand, it should consider the public health field. The social ability in buying toilet facilities MCK (bath, washing, and latrine) become a problem that needs attention but Poskedes and Posyandu become a motor of integrated health efforts for rural communities is a positive side.
\end{abstract}

Keywords: Control, Environmental Issues, Rural Institutions.

\section{Introduction}

Environmental-oriented development in rural areas is considered as sustainable development, this means that environmental management is an integrated effort to preserve the environmental function which includes the arrangement, maintenance, recovery, policy of utilization, supervision and control of the environment. Potential management of natural resources cannot be maximized in the future if the management practices implemented are not paying attention to the principles of sustainable development. Whereas natural resources and the environment are valuable assets for improving the welfare of rural communities if they are managed and utilized optimally, especially for the villagers [1]. However, a spatial plan for rural areas is needed. which is part of the district area is part of the district's spatial plan.This planning is the responsibility of the regional government. The spatial planning of rural areas in one district can be done at the level of the sub-district or some village areas [2]. Spatial planning in rural areas that includes two or more district areas is a coordination tool in the implementation of cross-regional development that combines the potential of each village Rural Area Development is a combination of $\mathrm{p}$ inter-village development carried out in an effort to accelerate rural development both infrastructure and infrastructure, improve service quality, empower communities through participatory development approaches [3]. 
The development of rural communities is part of community development which is directed also at institutional development and participation involving aspects of community empowerment in improving the welfare of rural units [4]. The tendency of people living in rural areas to have a low level of education and use of resources less optimal natural power in developing countries [5].

During this time rural areas are characterized by among others the low levels of labor productivity, the still high level of poverty, and the low quality of rural settlements [6]. The low productivity of labor in rural areas can be seen from the large number of workers accommodated in the agricultural sector [7]. The availability of infrastructure in rural areas also needs to be improved, both of which function to support economic activities and improve the quality of rural settlements [8]. Rural areas that are able to provide productive employment and a healthy and comfortable residential environment will be a deterrent to the migration of people from villages to cities as is done in China [9]. In sustainable environmental development, at least pay attention to natural resource management on a long-term basis, and quality improvement live the next generation [10], [11].

The effort to increase the carrying capacity of the environment by increasing the area of land used for agriculture is that the expansion was initially carried out on land suitable for agriculture, namely land that is flat or sloping and fertile in the villages in Wajo District. in Wajo District where the poor are still very large, which causes the need for household health facilities and infrastructure is very minimal, where some of the houses of the poor including livelihood categories are not suitable for living. Among the MCK facilities (eating, washing, latrines) for each household, especially poor people. In addition to the ability to procure MCK facilities, a problem is needed for socialization and counseling about the importance of these facilities to support the quality of healthy living for households and the environment.

Industrialization in Wajo District is based on agriculture, this provides the added value that remains in rural areas. To realize the improvement of the welfare of rural communities. Priority Plans for Village Governance, Village Development, Village Community Development, and Village Community Empowerment efforts to simultaneously diversify jobs need to be accompanied by increased rural community empowerment Transportation infrastructure development such as village roads for Marannu Village is a very urgent need. irrespective of the function of the village road which is so vital in supporting community activities, both as a means of transporting agricultural produce and as road access for the community in general. The development of rural communities to achieve prosperity based on environmental insight can be realized through village institutions as facilitators who can describe the problems faced. Therefore, the purpose of this research is to identify the circumstances and problems of the rural environment and analyze the efforts to control environmental problems through an institutional approach.

\section{Method}

This study uses a combination of research methods. This research method combines quantitative methods and qualitative methods. This research is based on the consideration that data will be obtained in a more complete, in-depth and reliable manner and can be found in social contexts. The informants in this study were community informants from three villages namely Marannu Village, Simpellu Village, and Tangkoro Village in Wajo District. The data analysis techniques used to solve problems in this study are qualitative and quantitative descriptive analysis. Activities in data analysis are data reduction, data display, and data verification. The average (mean) score is then grouped into three categories (1) Average 
score:> 3, (2) Medium classified as Average score: 2.5 - 3 (3) Low classified as Average score: $<2.5$.

\section{Result and Discussion}

\subsection{Identifying Village Conditions and Problems}

Based on the results of observations and interviews the function of roads in the village of Marannu is so vital in supporting community activities, both as a means of transporting agricultural produce as well as accessing the community in general. Even so, from the factual conditions that exist, it shows that the conditions in several sections have suffered severe damage caused by natural factors, especially in the prolonged rainy season. Likewise with the non-functioning of the drainage channel and a portion of the channel to drain the maximum household waste disposal is built or because of the lack of maintenance of the road suggestion. These conditions certainly have an impact on the daily activities of the community as road users.

In some places the community has not enjoyed electricity from the state electricity company (PLN). Likewise, there are still areas in Marannu Village that have not been accessed by Clean Water Facilities. Even though both of these things really determine the level of daily activities of the community. Likewise with the public service by the village government that has not been maximized because of the limited facilities and infrastructure to support the performance of village government officials. The problem is that the urgent need for the Marannu Village community is pioneering pavement and pavement along 1500 meters spread over three hamlets. The urgency of this need is because in addition to functioning as road access for community agriculture and plantations. In addition to improving the agricultural output of the community, the need for pioneering and pavement of farm roads still dominates the needs of the Marannu Village community. This is illustrated by the need for farm roads of \pm 4500 Meters.

Furthermore, in Simpellu Village the problems found in this study are the lack of Village Roads and some roads in the Village are damaged, so this has become a problem in supporting economic activities and daily activities of the community as road users. One of the causes of road damage in Simpellu Village is that there is rain every year while the roads are mostly not hardened.

On the other hand, public facilities and infrastructure such as kindergartens for improving human resources in Simpellu Village are still not optimal. It also includes village government institutions that still need adequate facilities and infrastructure such as the Office of the Village Consultative Body (BPD) and the incomplete Village Community Empowerment Institution for LPMD, as well as village offices that need more space to serve the community. The problem is also the lack of resources that function as water catchments, where in 2014 there was a long dry season. In Simpellu Village sources that function as water catchments such as village forests have been used as part of community plantations. On the other hand the land that is used by the community as a rice field area shows symptoms where soil fertility has begun to decrease, seen from the quality and yield of agriculture.

During the transition season people are very vulnerable to disease, this is also caused by environmental conditions that do not support. Like the availability of public toilets in every household not yet owned and also the absence of sewerage for household waste. Where household waste disposal is still around people's homes there is also the disposal of household waste to the rice fields. 
Then in Tangkoro Village, a number of problems were found, namely the maintenance of the shaft and hallways which were very late compared to what they should be, as well as the lack of farming roads. Education facilities have not been paid enough and classrooms are insufficient and there are still honor teachers who do not have benefits. The high dropout rate and lack of awareness of continuing education to college. The lack of attention and interest of the community towards the village community institutions. The potential for farmer groups that have been registered has not been maximized, as well as women's groups that still have to be fostered and developed, as well as the unavailability of community institutional buildings/offices.

Problems in the implementation of village development in Wajo District that appear generally are still related to village infrastructure management such as the Village Office Building still needs Rehabilitation so that services to the community are not comfortable and the Posyandu building is not sufficient to be occupied in Posyandu activities. Then another social problem is that there are still many Farmer Group Activities in the Hamlet that are not yet active and there are still school-age children who have not or have not attended school. Furthermore, the Taklim Council's activities have not been maximized because they have collided with funds that have not yet been maximized and also need to get the attention and security of the village still need to get attention.

Tabel 1. Distribution of Involvement in Environmental Problem Solving in Institutional Aspects

\begin{tabular}{llcc}
\hline Environmental Problems & Institutional involvement & Score & Interpretation \\
\hline Pests in Agricultural & Farmers Group, BPK & 1,3 & Low \\
Land & & & \\
Repair of MCK & BPD, Health Service & 2,71 & High \\
Clean Living Culture & The school & 3,0 & High \\
Dirty environment & PKK, Youth Institution & 2,3 & Medium \\
Household waste & PKK, Sanitation Service & 2,5 & Medium \\
Public Health Facilities & Village Health Post (Poskesdes) and Family & 3,1 & High \\
& Planning Service Post (Posyandu) & & \\
Community Social Issues & Youth Institution, Majelis Taklim & 2,4 & Medium \\
\hline
\end{tabular}

Source: Primary data, 2017.

Based on the table above it can be seen that there are a number of problems that have not been resolved optimally regarding environmental problems, namely the slum environment has a score of 2.3. Then for the problem of household waste has a score of 2.5. Then the social problems of the community were at a score of 2.4. These three problems showed the involvement of PKK, Youth Institution, Sanitation Office, Youth Institution, Taqlim Assembly, all of which were included in the medium category which meant that the problems still needed to be maximized while on pest problems on agricultural land including in the low category with a score of 1.3 this means that the farmer group which is considered to be still lacking in contribution. The real problem found was that there were still roads that needed pioneering and road hardening around $35 \mathrm{~km}$ in Simpellu Village, where the road was very 
useful for the community because it was a transportation route for agricultural products. Lack of water sources for Agriculture and Agricultural Infrastructure. The absence of pumping for irrigating rice fields, especially the dry season. Lack of agricultural equipment for farmers such as hand tractors that affect agricultural activities because people only use one tractor to meet farmers' needs so that traditional methods are still used so that it takes a long time for the rice processing.

\subsection{Efforts to Control Environmental Problems Through Institutional Approaches}

Government assistance, in this case, the agricultural service to the Bina Insani farmer group in dealing with rice pests by spraying land needs to be carried out intensively. Spraying for pest control is done naturally to eradicate pests, blast and provide fertility to rice stems. The involvement of the Agriculture Service and subdistrict extension agencies (BPK) is important, especially when assisting farmers. The direction of the strategy is to increase the productivity of farmers and plantations so that the standard of living of the community is better by: organizing farmer communities in order to achieve uniformity in carrying out activities, facilitating obtaining assistance from relevant agencies, establishing cooperation with all stakeholders, improving irrigation canals, rice fields, implementing arrangements integrated pest and disease control, development of farmers' balance and growth, provision of water sources for agricultural irrigation.

Policy direction and development priorities in Tangkoro village, Wajo Regency is the development of people's economy, in essence, is to manage all economic potentials that control the lives of many people by applying principles or principles of popular economy. The Government of Tangkoro Village gives the public the right and opportunity to have proportional economic access and expand the community's economic business in partnership. Rural economic development is in line with popular economic development. Rural economic development is carried out as an effort to increase community income and alleviate poverty in rural areas.

To further improve the level of public health, we need all the concerns, many things that sometimes become a problem for public health, the availability of infrastructure in the form of Posyandu, existing auxiliary health center need to get support to function well and optimally. Improvement of sanitation, MCK in the neighborhood of the community needs to get immediate attention so that health problems that often occur in communities such as Diarrhea, DHF and Malaria can be minimized.

The condition of the community in Marannu village where the poor are still very large, which causes the need for household health facilities and infrastructure is very minimal where some of the houses of the poor including livelihoods are not suitable for living. Among the MCK facilities for each household, especially the poor. for the provision of public toilets is a problem that is needed socialization and counseling about the importance of these facilities to support the quality of healthy living for households and the environment. Meeting the needs of nutritious food is a problem, given the economic level of the community, so that the quality of health is to support the quality of human resources, facilities and infrastructure health for Poskedes is very important for the health of mothers and children so that services in Poskesdes can be maximized. Poskedes and Posyandu are forms of community-based health efforts that are managed and organized from by and with the community in organizing health development to empower rural communities.

In the transition season many people contract the disease. Due to changes in weather and unclean environment. This happens because of the lack of socialization about the environment so that it needs to be improved. Control efforts can be made through public health centers that 
can make a series of community activities based on mutual cooperation and community selfhelp in order to recognize and solve problems or needs felt by the community, both in the health and fields in health-related fields, in order to be able maintain a healthy life in order to improve the quality of life and welfare of the community. This is also supported by healthy living habits in schools both elementary, high school and high school.

Tangkoro Village is known as a village that has a small number of young people and the young generation is a very large asset for the progress of the nation and the country, therefore the portion of attention from the government must be greater to this sector so that the youth development program runs well and succeed. The general purpose of a majlis taklim is to foster and develop a polite and harmonious relationship between humans and God, fellow human beings, and their environment in fostering people who are devoted to God.

The obstacles found in the institutional aspect are the lack of attention and interest of the community towards the village community institutions. The maximum potential of farmer groups that have been registered has not been maximized, as well as women's groups that still need to be fostered and developed, as well as the unavailability of buildings or community institutional offices.

The unavailability of a representative BPD Office. The competence and professionalism of BPD members and village staff including the hamlet heads must still be empowered and improved through education and training. Capacity strengthening is the process of enhancing the ability of other groups, organizations and institutions to understand and implement development in a broad sense on an ongoing basis [12], [13]. Capacity strengthening functions to foster community participation including strengthening the capacity of each individual community, institutional capacity including the ability and organizational values and network capacity with other institutions and the interaction with a wider system coverage is not only limited locally [14], [15].

Finally, this study found important descriptions related to local institutions that develop roles and functions in meeting the basic needs of rural communities that can be done in the form of guidance and provision of capital. This is adjusted to the characteristics of the target villages. in this study the characteristics of rural communities oriented to agricultural areas, which are not possible or developed by providing assistance, in addition to technology that is easy to obtain and minimal cost. It also provides space for both farmer groups that have the potential and ability to develop businesses that are supported by efforts to market agricultural products and infrastructure that consider socio-economic benefits for the development of public facilities and the development of village economic access. Institutional strengthening in order to fulfill basic needs can be implemented in an integrated manner.

\section{Conclusion}

This study found a number of problems that have not been resolved optimally related to environmental problems, namely the slum environment, the problem of house waste, social problems, various problems that show the involvement of PKK, Youth Institution, Sanitation Office, Youth Institution, Majelis Taqlim, all of which still need to be maximized while pest problems on agricultural land are things that should be prioritized, the support of farmer groups which are considered to be still lacking in contribution. The constraints found in the institutional aspect are the lack of attention and interest of the community towards the village community institutions. This can be seen from the lack of potential of the registered farmer groups. In the field of public health, the ability to procure MCK facilities is a matter of concern, but the existence of Poskedes and Posyandu is the driving force of integrated health 
efforts for rural communities. In addition, the competence and professionalism of BPD members and village staff including the hamlet heads must still be empowered and improved through education and training. Provision of adequate infrastructure and facilities support, government capacity building through a series of environmentally sound training can improve institutional capacity in rural areas.

\section{References}

[1] E. Hijriati and R. Mardiana, "Pengaruh Ekowisata Berbasis Masyarakat Terhadap Perubahan Kondisi Ekologi, Sosial dan Ekonomi di Kampung Batusuhunan, Sukabumi," J. Sosiol. Pedesaan, vol. 2, no. 3, pp. 146-159, 2014.

[2] M. Leach, R. Mearns, and I. Scoones, "Environmental entitlements: dynamics and institutions in community-based natural resource management," World Dev., vol. 27, no. 2, pp. 225-247, 1999.

[3] A. Bebbington, L. Dharmawan, E. Fahmi, and S. Guggenheim, "Local capacity, village governance, and the political economy of rural development in Indonesia jj," World Dev., vol. 34, no. 11, pp. 1958-1976, 2006.

[4] D. C. Korten, "Community organization and rural development: A learning process approach,” Public Administration Review. pp. 480-511, 1980.

[5] A. J. Hansen et al., "Ecological Causes and Consequences of Demographic Change in the New West: As natural amenities attract people and commerce to the rural west, the resulting land-use changes threaten biodiversity, even in protected areas, and challenge efforts to sustain 1," AIBS Bull., vol. 52, no. 2, pp. 151-162, 2002.

[6] M. Rasidi, "Review Program PNPM Mandiri Dalam Peningkatan Prasarana Kehidupan Masyarakat Di Desa Paowan Kabupaten Situbondo," Manag. Account. Res. J., vol. 1, no. 1, 2017.

[7] F. Kasryno, "Sumber daya Manusia dan pengelolaan lahan pertanian di pedesaan Indonesia," Forum Penelit. Agro Ekon., vol. 18, no. 1-2, pp. 25-51, 2016.

[8] I. J. Terluin, "Differences in economic development in rural regions of advanced countries: an overview and critical analysis of theories," J. Rural Stud., vol. 19, no. 3, pp. 327-344.

[9] M. Wen and G. Wang, "Demographic, psychological, and social environmental factors of loneliness and satisfaction among rural-to-urban migrants in Shanghai, China," Int. J. Comp. Sociol., vol. 50, no. 2, pp. 155-182, 2009.

[10] B. Rakic and M. Rakic, "Holistic Management Of Marketing Sustainability In The Process Of Sustainable Development," Environ. Eng. Manag. J., vol. 14, no. 4, pp. 887-900, 2015.

[11] L. N. Fonjong, N. N. Emmanuel, and C. C. Fonchingong, "Rethinking the contribution of indigenous management in small-scale water provision among selected rural communities in Cameroon," Environ. Dev. Sustain., vol. 6, no. 4, p. 429.

[12] L. Krantz, "The sustainable livelihood approach to poverty reduction," SIDA, Division for Policy and Socio-Economic Analysis. 2001.

[13] C. Lusthaus, M. H. Adrien, M. Perstinger, M. H. Adrien, and M. Perstinger, "Capacity development: definitions, issues and implications for planning, monitoring and evaluation," Universalia Occas. Pap., vol. 35, pp. 1-21, 1999. 
[14] R. J. Chaskin, "Building community capacity: A definitional framework and case studies from a comprehensive community initiative," Urban Aff. Rev., vol. 36, no. 3, pp. 291-323, 2001.

[15] A. Mathie and G. Cunningham, "From clients to citizens: Asset-based community development as a strategy for community-driven development," Dev. Pract., vol. 13, pp. 474-486, 2003. 